\title{
ANALISIS PERSEPSI MASYARAKAT TERHADAP KUALITAS PELAYANAN LEMBAGA KEUANGAN MIKRO (STUDI ANGGOTA BMT MARDHATILLAH BERKAH)
}

\author{
, Enjang Suherman 2) \\ Fakultas Bisnis dan Ilmu Sosial, Universitas Buana Perjuangan Karawang \\ Suroso@ubpkarawang.ac.id \\ Fakultas Bisnis dan Ilmu Sosial, Universitas Buana Perjuangan Karawang \\ Enjangsuherman@ubpkarawang.ac.id
}

\section{Abstrak}

Beberapa anggota BMT Mardhatillah Berkah pada perkembangannya banyak yang keluar pada tahun 2017, diindikasikan adanya ketidakpuasan atas pelayanan BMT Mardhatillah Berkah. Beberapa anggota beralasan bahwa ketidakpuasan tersebut meliputi sikap pegawai, kejelasan kebijakan, pelayanan yang cepat, fasilitas gedung kurang nyaman serta empati terhadap anggota. Oleh sebab itu, perlu dilakukan penelitian lebih lanjut dengan menganalisis kualitas pelayanan BMT Mardhatillah Berkah dengan menggunakan lima dimensi kualitas pelayanan. Kualitas pelayanan yang baik memiliki kesesuaian antara harapan dengan persepsi anggota.

Metode penelitian yang akan digunakan metode deskriptif kualitatif teknik analisis yang digunakan adalah Importance-Performance Analysis. Teknik pengumpulan data menggunakan wawancara dan angket, sedangkan teknik random sampling dan slovin dengan signifikansi $0,5 \%$ untuk sampelnya.

Hasil penelitian menyatakan bahwa persepsi anggota terhadap kualitas pelayanan BMT Mardhatillah Berkah baik. Tingkat posisi diagram kartesius menunjukkan untuk kuadran A seperti sopan-santun dan ramah-tamah, perhatian pegawai kepada anggota, kecepatan/ketepatan layanan dan fasilitas BMT perlu ditingkatkan kualitas pelayannya. Posisi kuadran B seperti seperti pegawai menguasai SOP, jaminan aman, dan komuniasi pegawai sudah baik perlu dipertahankan. Posisi kuadran C tidak ada faktor layanan di diagram kartesius tersebut. Terakhir kuadran D yaitu kualitas pelayanan dianggap terlalu berlebihan seperti waktu layanan sesuai jadwal, mudah ditemui/dihubungi, dan penampilan pegawai beranggapan terlalu berlebihan menurut anggota, namun bagi BMT merupakan standar prosedur yang telah ditetapkan.

Kata Kunci: Kualitas Pelayanan, Persepsi Anggota

\section{Abstract}

Members of BMT Mardhatillah Berkah on the growth of many out in 2017. Indicated their dissatisfaction with the services BMT Mardhatillah Berkah. Some members argued that such dissatisfaction include employee attitudes, policy clarity, fast service, building facilities less comfortable and empathy for members. Therefore, it is necessary to do further research to analyze the quality of service BMT Mardhatillah Berkah using five dimensions of service quality. Good service quality have suitability between members' expectations with perceptions of members.

The research method used descriptive qualitative methods, Analysis technique used is Importance-Performance Analysis. The technique of collecting data using interviews and questionnaires. while the technique of random sampling and slovin with a significance of $0.5 \%$ for the sample.

The result of research that members' perceptions of service quality BMT mardhatillah berkah is well. Level of position of the Cartesian diagram shows for quadrant " $A$ " like polite and welcoming, the attention of management to the member, fast services and facilities, all of them need to be improved service quality BMT. Position quadrant "B" like employee know SOP, guarantee, and communication of employees well, all need to be maintained. position quadrant " $C$ " there are not factor of service in the Cartesian diagram. the last quadrant " $D$ " that service quality is considered too excessive such as scheduled service time, easy to find / contact, and employee appearance, member assume too excessive. but for BMT is a standard procedure which has been established.

Key: service quality, perception member

\section{PENDAHULUAN}


BMT Mardhatillah Berkah salah satu BMT yang berada di daerah Karawang. Baitul Maal mengarah pada usaha-usaha pengumpulan dan penyaluran dana yang non profit, seperti zakat, infak dan shodaqoh. Sedangkan baitut tamwil sebagai usaha pengumpulan dan dan penyaluran dana komersil.

Anggota merupakan pelanggan BMT yang perlu diberikan pelayanan yang baik sehingga anggota BMT dapat merasa puas atas pelayanan yang dilakukan oleh manajemen BMT. BMT Mardhatillah Berkah berbadan hukum koperasi yang dikelola secara profesional sehingga terwujudnya kesejahteraan anggota. Selain itu, kualitas pelayanan juga dapat memperngaruhi kepuasan anggota yang dapat berdampak kepada eksistensi BMT itu sendiri karena anggota merupakan jiwanya sebuah koperasi.

BMT Mardhatillah Berkah berusaha untuk meningkat kualitas salah satunya kualitas pelayanan yang diberikan kepada anggotanya. Dengan memberikan fasilitas yang lengkap, pelayanan terpadu, pelatihan karyawan dan manajemen dan mempermudah akses pelayanan prima untuk membantu anggota BMT dalam keluh kesahnya selama menjadi anggota BMT Mardhatillah Berkah. Keberhasilan penyelengaraan lembaga keuangan didapat ketika mampu memberikan kepuasan kepada pelanggannya. Hal tersebut ditentukan dengan strategi yang tepat sesuai dengan situasi dan kondisi pada saat ini, yaitu dengan mengkaji karakteristik-karakteristik pelayanan seperti apa yang dibutuhkan dan diinginkan oleh pelanggannya.

Anggota memberikan persepsi baik terhadap pelayanan BMT ketika anggota mendapatkan pelayanan sesuai dengan harapan. Dengan demikian, maka kualitas pelayanan BMT akan menjadi daya saing tersendiri melebihi daya saing lembaga keuangan yang lain. Sebaliknya pelayanan yang tidak sesuai dengan harapan anggota maka BMT akan ditinggalkan.

Hubungan antara persepsi anggota atas kepuasannya terhadap kualitas pelayanan BMT dapat dilihat dari berbagai dimensi. Menrurut Parasuraman dan kawan-kawan terdapat 5 dimensi kualitas pelayanan yaitu:

1. Tangibles, atau bukti fisik yaitu kemampuan suatu lembaga keuangan dalam menunjukkan eksistensinya pada pihak eksternal.

2. Reliability, atau keandalan yaitu kemampuan lembaga keuangan untuk memberikan pelayanan sesuai yang dijanjikan secara akurat dan terpercaya.

3. Responsiveness, atau ketanggapan yaitu suatu kemauan untuk membantu dan memberikan pelayanan yang cepat (responsive) dan tepat kepada pelanggan, dengan penyampaian informasi yang jelas.

4. Assurance, atau jaminan dan kepastian yaitu pengetahuan, kesopan santunan, dan kemampuan karyawan dan manajemen lembaga keuangan untuk menumbuhkan rasa percaya pelanggan kepada lembaga keuangan.

5. Empathy, yaitu memberikan perhatian yang tulus dan bersifat individual atau pribadi yang diberikan kepada pelanggan dengan berupaya memahami keinginan pelanggan.

Dimensi-dimensi kualitas pelayanan ini yang menjadi fokus BMT Mardhatilah Berkah sebagai indikator dalam memberikan kepuasan kepada para anggotanya sehingga anggota dapat memanfaatkan pelayanan lembaga keuangan tersebut dalam upaya meninggkatkan kesejahteraan.

BMT Mardhatillah Berkah di dirikan pada tahun 2013 dengan pengesahaan akte pendirian oleh Dinas Koperasi dan UMKM Provinsi Jawa Barat. Perkembangan anggota BMT pada tahun 2017 terlihat bahwa mengalami penurunan jumlah anggota. Beberapa anggota keluar diindikasikan adanya ketidakpuasan atas pelayanan BMT Mardhatillah Berkah. Beberapa anggota beralasan bahwa ketidakpuasan tersebut meliputi sikap pegawai, kejelasan kebijakan, pelayanan yang cepat, fasilitas gedung kurang nyaman serta empati terhadap anggota. Walaupun demikian BMT selalu meningkatkan kualitas pelayanan dengan melakukan pelatihan dan pendidikan pegawai, menambah fasilitas kendaraan untuk membantu kecepatan pelayanan anggota dalam pembiayaan dan penagihan.

Pentingnya kualitas pelayanan menjadi prioritas utama bagi lembaga keuangan karena hal tersebut dinilai sejauh mana lembaga keuangan yaitu BMT memberikan kepuasan atas pelangganya. 
Lembaga perlu memahami setiap indikator kualitas pelayanan yang dianggap penting sesuai dengan harapan anggota. Kualitas pelayanan yang tidak sesuai dengan harapan akan menimbulkan kesenjangan. Kesenjangan tersebut terlihat akibat ketidaksesuaian persepsi anggota dengan kualitas pelayanan yang diberikan. Kualitas pelayanan harus sesuai atau lebih dari harapan yang dianggap penting bagi anggota. Ketika tingkat kesesuaian harapan dan persepsi sama besar maka terciptalah tingkat kepuasan yang optimal.

Manajemen lembaga keuangan dalam hal ini BMT Mardhatillah Berkah perlu dilakukan penelitian atas dimensi-dimensi kualitas pelayanan. Sehubungan dengan hal tesebut kami melakukan penelitian yang berjudul "Analisis Persepsi Masyarakat Terhadap Kualitas Pelayanan Lembaga Keuangan Mikro (Studi Anggota BMT Mardhatillah Berkah)."

Permasalahan yang terdapat pada pendahuluan tersebut dapat diajukan rumusan masalah sehingga dapat menjawab permasalah penelitian, yaitu: "Bagaimana persepsi anggota BMT Mardhatillah Berkah terhadap kualitas pelayanan dengan menggunakan dimensi keandalan, daya tanggap, jaminan, empati, dan bukti fisik."

Penelitian ini bertujuan untuk menguraikan permasalahan penelitian dengan menggunakan analisis persepsi anggota BMT Mardhatillah Berkah terhadap kualitas pelayanan dengan dengan menggunakan dimensi keandalan, daya tanggap, jaminan, empati, dan bukti fisik."

\section{LANDASAN TEORI}

\section{PERSEPSI ANGGOTA}

Menurut Kreitner dan Kinicki (2010:185) persepsi adalah merupakan kognitif yang memungkinkan seseorang menginterprestasikan dan memahami sekitarnya. Pemahaman dan interprestasi sekitar didapat ketika mendapat informasi dengan objek tersebut melalui interaksi sepenuhnya dengan lingkungan.

Persepsi juga dikatakan bahwa penyeleksian, pengaturan dan penginterprestasian dari input informasi untuk mendeskripsikan situasi yang ada. Bahwa persepsi anggota adalah gambaran berupa kesan anggota untuk memberikan sebuah makna yang diperoleh dari pemahaman suatu informasi terhadap objek yang dipersepsikan.

\section{KUALITAS PELAYANAN}

Kualitas layanan adalah tingkat keunggulan yang diharapkan dan pengendalian atas tingkat keunggulan tersebut untuk memenuhi keinginan pelanggan. Tingkat keunggulan tersebut dapat tercapai dalam pelayanan berkualitas dan kualitas produk. Fandy Tjiptono, (2004:61) mengatakan harapan pelanggan merupakan keyakinan pelanggan sebelum mencoba atau membeli suatu produk, yang dijadikan standar atau acuan dalam menilai kinerja produk bersangkutan. Setiap konsumen yang berbeda dapat menerapkan tipe ekspektasi yang berbeda untuk situasi yang berbeda.

Parasuraman, Zeithaml dan Berry mengemukakan bahwa terdapat lima dimensi layanan yang sering digunakan untuk mengukur kualitas layanan. Kelima dimensi tersebut adalah sebagai berikut.

a. Reliability (kehandalan), kemampuan untuk memberikan layanan yang dijanjikan secara akurat dan terpercaya.

b. Responsiveness (daya tanggap), kemauan untuk membantu pelanggan dan memberikan layanan yang cepat.

c. Assurance (jaminan), kemampuan, kesopanan dan pengetahuan pegawai untuk menumbuhkan kepercayaan dan keyakinan.

d. Empathy (empati), memberi perhatian personal kepada pelanggan.

e. Tangibles (bukti fisik), penampilan fasilitas fisik, peralatan, personel, dan materi-materi tertulis.

Mempertahankan anggota BMT supaya dapat menjadi pelanggan di lembaga keuangan, maka kualitas pelayanan menjadi perioritas utama dimana tingkat persepsi dan harapan pelanggan serta pelaksanaan kinerja lembaga lembaga keuangan harus sesuai. Lembaga harus memperhatikan halhal yang dianggap penting oleh anggota agar mereka merasa puas atas kualitas pelayanan yang diberikan. 
Oleh sebab itu, maka lembaga keuangan perlu menilai faktor-faktor yang akan mempengaruhi kualitas pelayanan. Didalam memberikan jasa pelayanan terdapat lima kriteria kualitas pelayanan yaitu daya tangkap, keandalan, jaminan, empati, dan bukti fisik (Parasuraman dkk 1985). Kelima unsur tersebut akan menjadi acuan utama dalam kerangka penelitian ini.

\section{Gambar 2 Operasional Variabel}
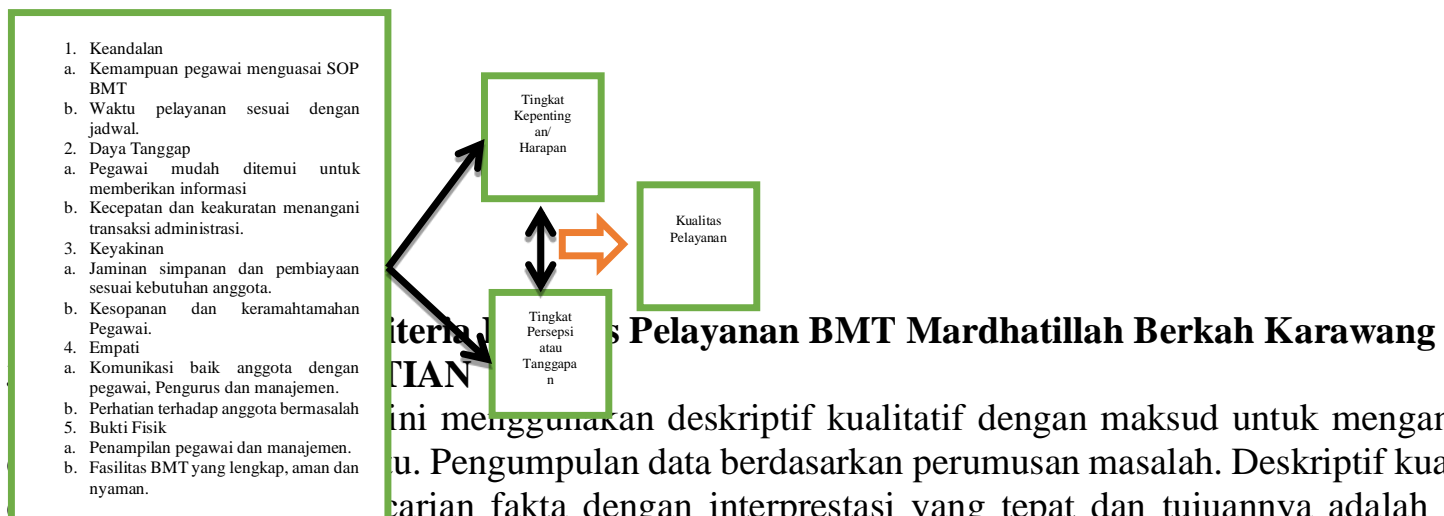

ini mengzumakan deskriptif kualitatif dengan maksud untuk menganalisis u. Pengumpulan data berdasarkan perumusan masalah. Deskriptif kualitatif :arian fakta dengan interprestasi yang tepat dan tujuannya adalah untuk mencari gambaran yang sistematis.

Lokus penelitian adalah BMT Mardhatillah Berkah. Adapun yang menjadi objeknya yaitu anggota, pegawai, pengurus dan manajemen sebagai respondennya.

Variabel persepsi anggota adalah tanggapan kesan anggota dalam menginterprestasikan makna yang diperoleh dari pengolahan informasi terhadap lingkungan. Adapun skala yang digunakan (sangat baik, baik, cukup baik, kurang baik, tidak baik). Sedangkan Variabel kualitas pelayanan merupakan kesesuaian antara harapan atau kepentingan anggota terhadap suatu pelayanan operasional dengan persepsi atau kepuasan yang didapat. Kesesuaian kualitas pelayananan didasarkan terhadap beberapa dimensi kualitas pelayanan meliputi daya tanggap, keandalan, jaminan, empati, dan bukti fisik. Skala yang digunakan sebagai alat ukur meliputi sangat penting, penting, cukup penting, kurang penting, tidak penting.
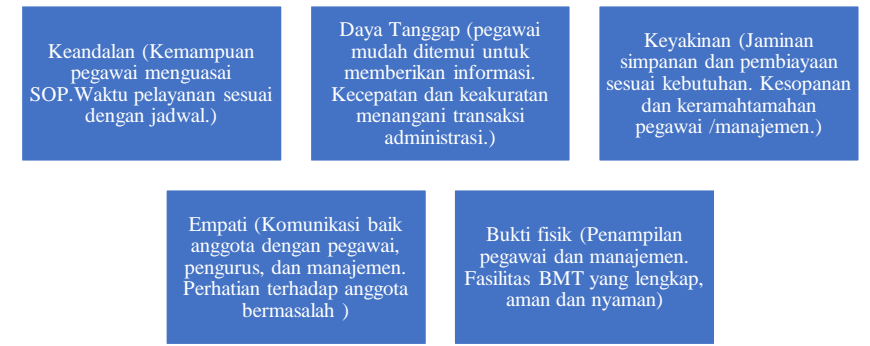

Populasi penelitian adalah seluruh anggota BMT Mardhatillah Berkah. Pengambilan sampel secara acak atau random sampling. Teknik random sampling menggunakan teknik slovin dengan tingkat kesalahnya 0,5\% yaitu anggota. Begitu juga dengan pegawai dan manajemen sebagai responden.

Analisis data penelitian menggunakan metode deskriptif kualitatif dengan menggunakan Importance-Performance Analysis atau IPA (Jonh A. Martila and John C. James, 1977) atau analisis kepentingan dan kinerja kepuasan pelanggan.(Supranto, 2011). IPA sebagai analisis dari jawaban rumusan masalah mengenai bagaimana persepsi anggota terhadap kualitas pelayanan BMT Mardhatillah Berkah. Sedangkan skala yang digunakan adalah skala likert terdiri dari tingkat kepentingan dan tingkat persepsi yaitu: 
Tingkat kepentingan diberikan bobot yaitu: (a) Jawaban tidak penting diberi bobot 1; (b) Jawaban kurang penting diberi bobot 2; (c) Jawaban cukup penting diberi bobot 3; (d) Jawaban penting diberi bobot 4; (e) Jawaban sangat penting diberi bobot 5. Sedangkan Tingkat Persepsi diberikan penilaian dengan bobot sebagai berikut: (a) Jawaban tidak baik diberi bobot 1; (b) Jawaban kurang baik diberi bobot 2; (c) Jawaban cukup baik diberi bobot 3; (d) Jawaban baik diberi bobot 4; (e)Jawaban sangat baik diberi bobot 5 .

Hasil data penelitian mengenai tingkat kepentingan dan penilaian persepsi perlu dilakukan suatu perhitungan mengenai tingkat kesesuaian antara tingkat kepentingan dengan tingkat persepsi anggota. Tingkat kesesuaian merupakan hasil perbandingan skor persepsi dengan skor kepentingan. Tingkat kesesuaian yang akan menentukan urutan prioritas peningkatan faktor-faktor yang mempengaruhi kualitas pelayanan.

Adapun rumus yang digunakan adalah: $T k i=\frac{X i}{Y i} \times 100 \%$; Dimana : Tki $=$ tingkat kesesuaian responden; $\mathrm{Xi}=$ skor persepsi anggota; $\mathrm{Yi}=$ skor penilaian kepentingan pelanggan.

Sumbu tegak (Y) akan diisi oleh skor tingkat kepentingan, yang lainnya sumbu mendatar (X) akan diisi oleh skor tingkat persepsi. Dengan demikian rumus adalah:

$\bar{X}=\frac{\sum X i}{n} ; \bar{Y}=\frac{\sum Y i}{n} ; \bar{X}=$ skor rata-rata tingkat persepsi; $\bar{Y}=$ skor rata-rata tingkat kepentingan; $\mathrm{n}$ $=$ jumlah responden. Selain itu, terdapat suatu diagram yakni diagram kartecius yang merupakan suatu bangun dibagi atas empat bagian dan dibatasi oleh dua buah garis berpotongan tegak lurus pada titik $(\overline{\bar{X}}, \overline{\bar{Y}}) . \overline{\bar{Y}}$ merupakan rata-rata dari skor rata-rata tingkat kepentingan seluruh faktor atau atribut dan $\overline{\bar{X}}$ merupakan rata-rata dari rata-rata skor tingkat persepsi anggota seluruh faktor atau atribut. Seluruh atribut ada 10 atau $\mathrm{K}=10$ maka selanjutnya rumus.

$\overline{\bar{X}}=\frac{\sum_{i=1}^{n} \overline{X \imath}}{K} \quad \overline{\bar{Y}}=\frac{\sum_{i=1}^{n} \overline{Y \imath}}{K}$

$\mathrm{K}$ adalah beberapa faktor yang menjadi indikator kualitas pelayanan.

Maka digaram kartesiusnya yaitu:

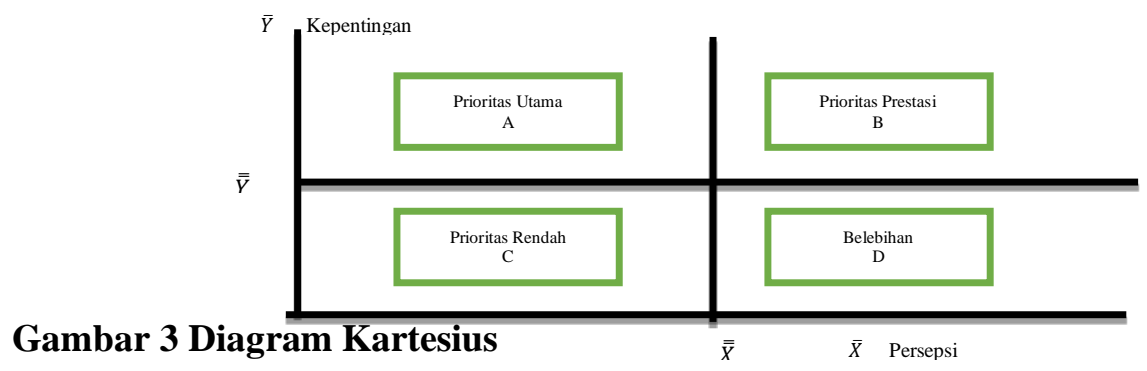

Keterangan:

A. Menunjukan indikator yang dianggap penting dapat mempengaruhi kualitas pelayanan, namun manajemen belum melakukan pelaksanaan pelayanan tersebut sesuai keinginan anggota.

B. Menunjukan indikator faktor pelayanan yang telah berhasil dilaksanakan manajemen oleh sebab itu wajib dipertahankan.

C. Menunjukan faktor yang kurang penting mempengaruhi pelayanan, pelaksanaan bagi BMT dianggap sudah cukup.

D. Menunjukan faktor yang kurang penting mempengaruhi anggota ,akan tetapi pelaksanaan pelayanan berlebihan menurut anggota.

\section{HASILDAN PEMBAHASAN}

Berdasarkan data terbaru bulan Mei 2018 jumlah populasi adalah 454. Maka dengan menggunakan rumus slovin didapatkan: $n=\frac{454}{1+454(0,05)^{2}}=213$ 
Berdasarkan pengumpulan data yang dilakukan secara random sampling melalui angket penelitian didapatkan data angket sebagai berikut:

Tabel 1 Data Kuesioner Anggota

\begin{tabular}{c|l|c|c|c|c|c|c|c|c|c|c}
\hline \multirow{2}{*}{ No } & \multirow{3}{*}{ KETERANGAN } & \multicolumn{5}{|c|}{ PENILAIAN PERSEPSI } & \multicolumn{5}{c}{ PENILAIAN HARAPAN } \\
\cline { 3 - 11 } & 1 & 2 & 3 & 4 & 5 & 1 & 2 & 3 & 4 & 5 \\
\hline I & $\begin{array}{l}\text { Pegawai mengusai } \\
\text { Sop }\end{array}$ & 0 & 9 & 43 & 126 & 35 & 0 & 0 & 12 & 80 & 121 \\
\hline II & $\begin{array}{l}\text { Waktu layanan sesuai } \\
\text { jadwal }\end{array}$ & 0 & 6 & 66 & 109 & 32 & 0 & 1 & 27 & 93 & 92 \\
\hline III & $\begin{array}{l}\text { Mudah ditemui/ } \\
\text { hubungi }\end{array}$ & 0 & 9 & 98 & 60 & 46 & 0 & 0 & 14 & 101 & 98 \\
\hline IV & $\begin{array}{l}\text { Kecepatan/ketepatan } \\
\text { layanan }\end{array}$ & 3 & 27 & 67 & 86 & 30 & 0 & 0 & 12 & 100 & 101 \\
\hline V & Jaminan aman & 0 & 2 & 34 & 119 & 58 & 0 & 0 & 4 & 89 & 120 \\
\hline VI & $\begin{array}{l}\text { Sopansantun dan } \\
\text { ramahtamah }\end{array}$ & 2 & 26 & 55 & 101 & 29 & 0 & 0 & 11 & 98 & 104 \\
\hline VII & Komunikasi pegawai & 0 & 7 & 66 & 113 & 27 & 0 & 2 & 17 & 86 & 108 \\
\hline VIII & $\begin{array}{l}\text { Perhatian pegawai } \\
\text { kpd anggota }\end{array}$ & 10 & 18 & 78 & 78 & 29 & 0 & 2 & 13 & 88 & 110 \\
\hline IX & Penampilan pegawai & 0 & 6 & 60 & 116 & 31 & 0 & 0 & 38 & 107 & 68 \\
\hline X & Fasilitas BMT & 13 & 68 & 61 & 60 & 11 & 0 & 4 & 17 & 46 & 146 \\
\hline & Jumlah & 28 & 178 & 628 & 968 & 328 & 0 & 9 & 165 & 888 & 1068 \\
\hline
\end{tabular}

Sumber: Data primer, olah data 2018

Data Kuesioner Anggota BMT Mardhatillah Berkah terhadap kualitas pelayanan menunjukan bahwa penilaian persepsi anggota terhadap kualitas pelayanan paling banyak menunjukan pada nilai empat dengan skor jumlah 968, artinya kualitas pelayanan dipersepsikan baik. Sedangkan penilaian persepsi yang paling sedikit menunjukan nilai satu dengan skor jumlah 28 , artinya kualitas pelayanan dipersepsikan sangat tidak baik.

Adapun data kuesioner Anggota BMT Mardhatillah Berkah terhadap kualitas pelayanan untuk harapan yang diiginkan oleh anggota paling banyak menunjukan nilai lima dengan skor jumlah 1068, artinya kualitas pelayanan yang diharapkan sangat penting. Sedangkan penilaian harapan yang paling sedikit menunjukan nilai satu dengan skor jumlah 0 , artinya kualitas pelayanan diharapkan sangat tidak penting.

Analisis hasil kuesioner selanjutnya dihitung atas tingkat kesesuaiinya. Tingkat kesesuaian adalah hasil perbandingan skor kinerja (persepsi) dengan skor kepentingan. Tingkat kesesuaian yang akan menentukan urutan prioritas peningkatan faktor-faktor yang mempengaruhi kualitas pelayanan. Adapun rumus yang digunakan adalah: $T k i=\frac{X i}{Y i} \times 100 \% ; \mathrm{Tki}=$ tingkat kesesuaian responden; $\mathrm{Xi}$ $=$ skor persepsi anggota $; \mathrm{Yi}=$ skor penilaian kepentingan anggota.

Maka diperoleh hasilnya pada tabel 5.4 sebagai berikut:

Tabel 2 Hasil Rekapitulasi Tingkat Kesuaian Persepsi Dengan Harapan

\begin{tabular}{|c|c|c|c|c|c|c|c|c|c|c|c|c|c|}
\hline \multirow{2}{*}{ ATRIBUT } & \multicolumn{5}{|c|}{ SKOR PERSEPSI } & \multirow{2}{*}{ JML } & \multicolumn{5}{|c|}{ SKOR HARAPAN } & \multirow{2}{*}{ JJML } & \multirow{2}{*}{$\begin{array}{l}\text { KESESUAIAN } \\
(\%)\end{array}$} \\
\hline & 1 & 2 & 3 & 4 & 5 & & 1 & 2 & 3 & \begin{tabular}{|l|l|}
4 \\
\end{tabular} & 5 & & \\
\hline $\begin{array}{l}\text { Pegawai } \\
\text { mengusai Sop }\end{array}$ & 0 & 18 & 129 & 504 & 175 & 826 & 0 & 0 & 36 & 320 & 605 & 961 & 85,95 \\
\hline $\begin{array}{l}\text { Waktu layanan } \\
\text { sesuai jadwal }\end{array}$ & 0 & 12 & 198 & 436 & 160 & 806 & 0 & 2 & 81 & 372 & 460 & 915 & 88,09 \\
\hline $\begin{array}{l}\text { Mudah ditemui/ } \\
\text { hubungi }\end{array}$ & 0 & 18 & 294 & 240 & 230 & 782 & 0 & 0 & 42 & 404 & 490 & 936 & 83,55 \\
\hline $\begin{array}{l}\text { Kecepatan/ketepat } \\
\text { an layanan }\end{array}$ & 3 & 54 & 201 & 344 & 150 & 752 & 0 & 0 & 36 & 400 & 505 & 941 & 79,91 \\
\hline Jaminan aman & 0 & 4 & 102 & 476 & 290 & 872 & 0 & 0 & 12 & 356 & 600 & 968 & 90,08 \\
\hline $\begin{array}{l}\text { Sopansantun dan } \\
\text { ramahtamah }\end{array}$ & 2 & 52 & 165 & 404 & 145 & 768 & 0 & 0 & 33 & 392 & 520 & 945 & 81,27 \\
\hline $\begin{array}{l}\text { Komunikasi } \\
\text { pegawai }\end{array}$ & 0 & 14 & 198 & 452 & 135 & 799 & 0 & 4 & 51 & 344 & 540 & 939 & 85,09 \\
\hline $\begin{array}{l}\text { Perhatian pegawai } \\
\text { kpd anggota }\end{array}$ & 10 & 36 & 234 & 312 & 145 & 737 & 0 & 4 & 39 & 352 & 550 & 945 & 77,99 \\
\hline $\begin{array}{l}\begin{array}{l}\text { Penampilan } \\
\text { pegawai }\end{array} \\
\end{array}$ & 0 & 12 & 180 & 464 & 155 & 811 & 0 & 0 & 114 & 428 & 340 & 882 & 91,95 \\
\hline Fasilitas BMT & 13 & 136 & 183 & 240 & 55 & 627 & 0 & 8 & 51 & 184 & 730 & 973 & 64,44 \\
\hline
\end{tabular}


Sumber: Data primer, olah data 2018

Diagram kaertesium terbagi menjadi empat bagian untuk melihat posisi data yang sudah dianalisis, keempat bagian tersebut meliputi:

A. Menunjukan indikator yang dianggap penting dapat mempengaruhi kualitas pelayanan, namun manajemen belum melakukan pelaksanaan pelayanan tersebut sesuai keinginan anggota.

B. Menunjukan indikator faktor pelayanan yang telah berhasil dilaksanakan manajemen oleh sebab itu wajib dipertahankan.

C. Menunjukan faktor yang kurang penting mempengaruhi pelayanan, pelaksanaan bagi manajemen biasa-biasa saja menurut BMT.

D. Menunjukan faktor yang kurang penting mempengaruhi anggota ,akan tetapi pelaksanaan pelayanan berlebihan menurut anggota.

Tabel 3 Rekapitulasi Rata-rata penilaian persepsi dan kepentingan pelayanan BMT Mardhatillah Berkah dalam membuat diagram kartesius

\begin{tabular}{|c|c|c|c|c|c|}
\hline No & $\begin{array}{l}\text { Faktor pelayanan } \\
\text { perguruan tinggi }\end{array}$ & Persepsi & Harapan & $\bar{X}$ & $\bar{Y}$ \\
\hline 1 & $\begin{array}{l}\text { Pegawai mengusai Sop } \\
\end{array}$ & 826 & 961 & 3,88 & 4,51 \\
\hline 2 & $\begin{array}{c}\text { Waktu layanan sesuai } \\
\text { jadwal }\end{array}$ & 806 & 915 & 3,78 & 4,30 \\
\hline 3 & mudah ditemui/ hubungi & 782 & 936 & 3,67 & 4,39 \\
\hline & kecepatan/ketepatan & & & & \\
\hline 4 & layanan & 752 & 941 & 3,53 & 4,42 \\
\hline 5 & Jaminan aman & 872 & 968 & 4,09 & 4,54 \\
\hline & sopansantun dan & & & & \\
\hline$\frac{6}{7}$ & $\begin{array}{l}\text { ramahtamah } \\
\text { komunikasinegawa }\end{array}$ & $\frac{768}{799}$ & $\frac{945}{939}$ & $\frac{3,61}{375}$ & $\frac{4,44}{441}$ \\
\hline 7 & $\begin{array}{l}\text { komunikasi pegawai } \\
\text { Perbatian pegawaiknd }\end{array}$ & & & & \\
\hline 8 & $\begin{array}{l}\text { Perhatian pegawai kpd } \\
\text { anggota }\end{array}$ & 737 & 945 & 3,46 & 4,44 \\
\hline 9 & Penampilan pegawai & 811 & 882 & 3,81 & 4,14 \\
\hline 10 & Fasilitas BMT & 627 & 973 & 2,94 & 4,57 \\
\hline \multicolumn{2}{|c|}{ Rata-Rata $(\overline{\bar{X}} \operatorname{dan} \overline{\bar{Y}})$} & & & 3,65 & 4,42 \\
\hline
\end{tabular}

Sumber: Data primer, olah data 2018

Tabel 3 menunjukan nilai rata-rata untuk sumbu x sebesar 3,65 sedangkan sumbu y sebesar 4,42 sebagai garis pembelahnya sehingga dapat dibuat gambar diagram kartesius sebagai berikut:

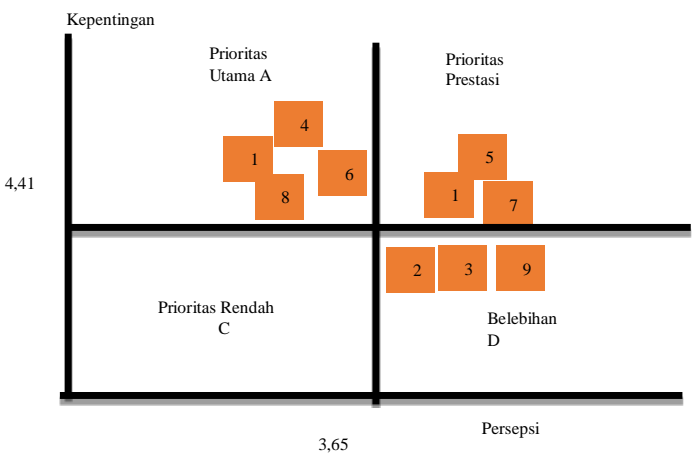

Gambar 4 Diagram Kartesius Pelayanan

PEMBAHASAN

Sumber: Olah data primer, 2018

Pengukuran tingkat kepentingan dengan persepsinya atas pelayanan yang diberikan oleh Lembaga Baitul Maal Wa Tamwil Mardhatillah Berkah dapat dilihat hasil diagram kartesius. Posisi penempatan data yang telah dianalisis, telah dibagi menjadi empat bagian. Empat bagian tersebut dapat menjadi acuan untuk perbaikan dikemudian hari demi mewujudkan kualitas pelayanan prima sesuai dengan kepentingan anggota sehingga kepuasan anggota dapat terjadi.

Empat kuadran dalam diagram kartesius tersebut terbagi menjadi kuadran A, kuadran B, kuadran C, dan kuadran D, sebagai berikut:

1. Kuadran A

Pada kuadran A ini menunjukan bahwa faktor-faktor pelayanannya perlu diprioritaskan oleh

BMT, karena faktor pelayanan tersebut dianggap penting oleh anggota sehingga dapat 
mempengaruhi kualitas pelayanan, namun BMT dalam pelaksanaanya belum melakukan pelayanan tersebut sesuai keinginan anggota.

Faktor pelayanan pada kuadran ini meliputi

a. Sopan-santun dan ramah tamah pada posisi koordinat $(3,61 ; 4,44)$ dengan nomor 6 .

Perilaku merupakan aspek paling penting dalam memberikan pelayanan prima, $5 \mathrm{~S}$ yaitu senyum, salam, sapa, sopan dan santun harus diterapkan untuk setiap pegawai Lembaga keuangan mikro terutama pegawai BMT Mardhatillah Berkah. Berdasarkan hasil analisis perilaku pegawai BMT tersebut belum terealisasi dilapangan, menggap bahwa sebagian anggota masih kurang nyaman atas perilaku pegawai BMT seperti cara menagih. Menurut pengakuan dari pihak BMT, pegawainya berupaya mewujudkan budaya $5 \mathrm{~S}$ tersebut, namun berbeda pada saat dilapangan. Hal ini dikarenakan kondisi masyarakat / anggota yang macet sering membuat emosi pegawai BMT tersebut. Terkadang anggota macet sering memberikan harapan palsu sehingga pegawai sering bolak-balik ke rumah anggota tersebut dan memberikan kesan "ketus dan judes". Hal ini bisa menjadi pemicu kurang optimumnya faktor pelayanan ini.

b. Perhatian pegawai kepada anggota pada koordinat $(3,46 ; 4,44)$ dengan nomor 8

Perhatian pegawai kepada anggota dianggap kurang optimal dalam pelaksanaannya. Berdasarkan hasil analisis menunjukan bahwa persepsi anggota menunjukan penilaian cukup baik dengan nilai rekapitulasi 78. Menurut anggota belum ada penghargaan atas prestasi kelancaran pembayaran maupun memberikan solusi atas kemacetan pembiayaan seperti ditambah lagi dana pembiayaan. Namun menurut pihak BMT mengakui belum reward bagi anggota lancer dikarenakan memerlukan modal yang lebih besar, namun BMT berusaha sebaik mungkin memeberikan penghargaan tersebut yang sudah dilakukan berupa pemberian banner untuk anggota yang lancer. Sedangkan untuk anggota yang macet perhatiannya berupa pendampingan dan pemberian waktu tenggang atas pembayaran angsurannya. BMT juga pernah melakukan tindakan resecheduling untuk meringankan anggota yang macet.

c. Kecepatan/ketepatan layanan pada posisi koordinat $(3,53 ; 4,42)$ dengan nomor 4

Kecepatan dan pelayanan administrasi dalam dunia Lembaga keuangan sangat diperlukan, hal ini tentunya anggota tidak menginginkan menunggu terlalu lama di dalam ruang tunggu. Pelayanan kecepatan dan ketepatan pelayanan di BMT menurut persepsi anggota kurang optimal sedangkan kepentingan atau keinginan pelayanan tersebut lebih cepat dan tepat. Menurut pendapat pihak BMT mengklaim pelayanan sudah cukup cepat, ketika ada pengajuan langsung diproses dengan survey pada hari tersebut. Apabila dinyatakan layak maka pada hari yang sama dicairkan pembiayaannya. Apabila ada penolakan diberi waktu setelah komite kredit. Pada jeda waktu tersebut anggota terkadang marah-marah dan langsung diberi tahu alasan tidak dicairkan.

d. Fasilitas BMT pada posisi koordinat $(2,94 ; 4,57)$ dengan nomor 10

Fasilitas baik dan nyaman merupakan idaman untuk semua bentuk pelayanan. Namun tidak begitu dirasakan oleh anggota BMT Mardhatillah Berkah. Anggota membuat persepsi bahwa fasilitas BMT kurang baik hal ini ditunjukan dengan kesesuaianya hanya sebesar $64,99 \%$ nilai terendah dari semua faktor pelayanan. Ada sebagian anggota menginginkan fasilitas bayar angsuran di minimarket atau toko terdekat untuk mempermudah pembayaran, sedangkan untuk mengantar angsuran ke kantor dirasa cukup jauh dan menunggu petugas BMT datang ke rumah dirasakan selalu lama untuk ditunggu. Selain itu juga anggota menginginkan adanya transfer seperti hanya bank umum. Adapun pendapat BMT fasilitas yang tersedia dirasakan alhamdulillah seperti komputer,kendaraan untuk kolektor sudah disiapkan untuk mempermudah layanan. Namun sampai saat ini belum ada kerjasama dengan minimarket karena ada administrasi. Kebanyakan anggota tidak menginkan potongan adminitrasi. Selama ini untuk mempermudah layanan BMT untuk angsuran dapat 
ditransfer melalui bank umum yang sudah ditunjuk sebelumnya tanpa dibebankan biaya administrasi kepada anggota.

2. Kuadran B

Pada kuadran B ini menunjukan faktor-faktor pelayanannya perlu dipertahankan, karena pelaksanaanya sesuai dengan kepentingan dan harapan anggota. Oleh sebab itu, persepsi bai katas pelayanan BMT.

Faktor-faktor pelayanan pada kuadran ini meliputi:

a. Pegawai mengusai standar operasional prosedur pada posisi koordinat $(3,88 ; 4,51)$ dengan nomor 1

Standar operasional prosedur yang sudah ditetapkan oleh BMT untuk kualitas pelayanan telah dilaksanakan dengan baik menurut persepsi anggota, BMT harus mempertahankan faktor layanan tersebut dengan selalu memberikan pelatihan kepada pegawainya.

BMT mengklaim bahwa setiap bulannya ada pelatihan keanggotaan sehingga pelayanan kepada anggo lebih baik. Bentuk pelatihannya berupa seminar, adapun pelaksanaannya dari pihak BMT atau dari pihak Dinas Koperasi Provinsi. Pelatihan ke-BMT-an telah dilakukan pada tahun 2016 di kujang. Seminar dari Dinas Koperasi dan UMKM Provinsi BMT di undang ke Bandung dan mengirimkan perwakilannya. Pelatihannya terkadang di kantor dinas atau ditempat lain seperti koperasi lain. Pelatihan tersebut berupa manajemen dan akuntansi. sedangkan pelatihan pemasaran belum ada.

b. Jaminan aman pada posisi koordinat $(4,09 ; 4,54)$ dengan nomor 5

Jaminan aman merupakan prestasi kedua yang perlu dipertahankan. Barang yang disimpan di BMT wajib dikembalikan secara utuh kepada anggota. Selama ini belum ada keluhan atas kehilangan barang jaminan di BMT. BMT menjelaskan memiliki berangkas khusus yang disimpan di kantornya. Barang jaminan tersebut dapat berupa sertifikat, bpkb, ijazah atau surat berharga lain yang dianggap penting dan disimpan dengan aman.

c. Komunikasi pegawai pada posisi koordinat $(3,75 ; 4,41)$ dengan nomor 7

Komunikasi adalah metode dalam menyampaikan suatu informasi kepada angota. Kominkasi yang baik pegawai kepada anggota merupakan hal yang diingikan. Oleh sebab itu, komunikasi yang baik tersebut perlu dipertahankan. BMT menjelaskan selama ini untuk berkomunkasi dengan anggota dengan media sosial seperti whats'up atau BBM. Hal ini mempermudah untuk menjalin silaturahmi dengan anggota walaupun terkedala jarak tempuh. Medsos tersebut bisa digunakan sebagai alat salam-sapa, pengajuan, serta penangihan yang sudah jatuh tempo untuk mengingatkan kembali kepada anggota yang lupa akan angsurannya.

3. Kuadran C

Pada kuadran $\mathrm{C}$ ini menunjukan faktor-faktor pelayanan yang masih dianggap kurang penting bagi bagi anggota. Namun dalam pelaksanaanya . Sedangkan pelaksanaan pelayanan yang diberikan dianggap sudah cukup.

Faktor-faktor pelayanan pada kuadran ini tidak ada. Sehingga tidak ada pembahasan dalam kuadran C.

4. Kuadran D

Pada kuadran D ini menunjukan faktor-faktor pelayanan yang dinilai berlebihan dalam pelaksanaan. Anggapan anggota bahwa pelayanan yang diberikan kurang penting sedangkan pelaksanaan pelayanan sangat baik.

Faktor-faktor pelayanan pada kuadran ini meliputi:

a. Waktu layanan sesuai jadwal pada koordinat $(3,78 ; 4,39)$ dengan nomor 2

Pelayanan sesuai dengan jadwal merupakan ketepatan waktu penagihan atau pengambilan angsuran. Selain itu juga, buka dan tutup kantor BMT tepat pada waktunya, yaitu hari senin sampai dengan hari jum'at jam 08.00-17.00, kecuali hari libur. Persepsi anggota beranggapan tidak terlalu penting untuk layanan sesuai jadwal. Anggota menginginkan ada 
kelonggaran atas jadwal tagihan. Akan tetapi bagi BMT hal tersebut merupakan prosedur yang harus dijalankan. Terkadang anggota yang telat angsuran sering diingatkan sebelum jatuh tempo.

b. Mudah ditemui/dihubungi pada koordinat $(3,67 ; 4,39)$ dengan nomor 3

Persepsi anggota menilai bahwa pegawai mudah untuk dihubungi atau terlalu berlebihan. Terkadang ada anggota perempuan yang tidak menginginkan suaminya mengatahui atas utangnya kepada BMT, namun penagihan lewat medsos tersebut diketahui oleh suaminya. Sedangkan dari pihak BMT hal tersebut merupakan salah satu prosedur penagihan.

c. Penampilan pegawai pada koordinat $(3,81 ; 4,41)$

Penampilan fisik pegawai merupakan salah satu bukti fisik untuk melayani langsung dengan anggota. Penampilan pegawai yang rapih, bersih dan harum dapat memberikan kenyamanan secara kasat mata oleh anggota ketika pegawai sedang memeberikan pelayanan kepadanya. Menurut persepsi anggota untuk tingkat koperasi tidak perlu serapi pegawai bank, cukup tidak bau badan saja ketika pelayanan dilapangan. BMT berpendapat bahwa untuk memberikan pelayanan kepada anggota harus maksimal karena BMT mempunyai moto "pelayanan secepat rentenir, serapih bank". Pelayanan tersebut seperti setiap hari pakai seragam, terkadang menggunakan batik, tidak boleh menggunakan kaos, sandal kecuali sepatu boot pada waktu hujan (khusus petugas lapangan).

\section{KESIMPULAN}

Kesimpulan yang didapat atas berdasarkan hasil analisis dan pembahasan yang telah diuraikan pada bab sebelumnya sebagai berikut:

Persepsi anggota BMT Mardhatillah berkah terhadap Lembaga keuangan tersebut dinilai sudah baik, hal tersebut bisa dilihat dari rekapitulasi jawaban persepsi anggota paling banyak menunjukan pada nilai empat dengan skor jumlah 968, artinya kualitas pelayanan dipersepsikan baik. Untuk tingkat kesesuaian pelayanan sekitar $80 \%-90 \%$ apabila dirata-ratakan. Sedangkan posisi pada diagram kartesius menunjukan pada kuadran A seperti sopan-santun dan ramah-tamah, perhatian pegawai kepada anggota, kecepatan/ketepatan layanan dan fasilitas BMT perlu ditingkatkan kualitas pelayannya. Adapun pada posisi kuadran D kualitas pelayanan dianggap terlalu berlebihan seperti waktu layanan sesuai jadwal, mudah ditemui/dihubungi, dan penampilan pegawai beranggapan terlalu berlebihan menurut anggota, namun bagi BMT merupakan standar prosedur yang telah ditetapkan. Pada posisi kuadran B merupakan prestasi kualitas pelayanan yang perlu dipertahankan, pelayanan tersebut sudah sesuai dengan keinginan anggota seperti pegawai menguasai SOP, jaminan aman, dan komuniasi pegawai sudah baik. Sedangkan pada kuadran C tidak ada faktor layanan di diagram kartesius tersebut.

\section{REFERENSI}

Gaspersz, Vincent. 1997. Manajemen Bisnis Total dalam Era Globalisasi. Jakarta : Penerbit PT.Gramedia.

J.Supranto. 2011. Pengukuran tingkat kepuasan pelanggan. Jakarta: Rineka Cipta

Kirom, Bahrul. 2013. Mengukur Kinerja Pelayanan dan Kepuasan Konsumen cetakan 3. Bandung: Pustaka Reka cipta

Kotler, Phillip. 1995. Marketing Management Analysis, Planning, Implementation\& Control. Prentice Hall Int,Kreitner, Robert and Angelo Kinicki. 2010. Organizational Behavior. New York: McGraw-Hill

Kotler, Philip. 1994. Marketing Manajemen:Analisys, Planning, Implementation \& Control. Prentice Hall International Editions: Eighth Edition

McShane, Steven L. And Mary Ann Von Glinoe. 2006. Worley. Built to change. San Francisco: John Wiley \& Sons, Inc. 
Miftah Thoha. 2003, Kepemimpinan Dalam Manajemen Jakarta : PT. Raja Grafindo Persada.

Parasuraman, A; Zeithaml, V.A; and Berry, L.L., 1985. A Conceptual Model of Sevice Quality and its Implications for Future Research. Jurnal of Marketing (fall)

Robbin, Stephen P. And Timonthy A. Judge. 2011. Organizational Behavior. New Jersey: Pearson Education. Inc.

Suherman, Enjang. 2017. Analisis Perbedaan Kualitas Pelayanan Lembaga Keuangan Mikro Ksp. Mugi Lestari Syariah Dengan Bmt Mardhatillah Berkah. Karawang: Jurnal Buana Ilmu, Universitas Buana Perjuangan Karawang. Vol 1 No 2.

Suroso. 2017. Analisis Persepsi Mahasiswa Terhadap Kualitas Pelayanan Universitas Buana Perjuangan Karawang (Program Studi Manajemen). Karawang: Jurnal Buana Ilmu, Universitas Buana Perjuangan Karawang. Vol 1 No 2.

Tjiptono, Fandi. 2004. Strategi Pemasaran, edisi kedua. Yogyakarta: Andi Ofset

Thomas Stefanus Kaihatu. 2008. Analisis kesenjangan kualitas pelayanan dan kepuasan konsumen pengunjung Plasa Tanjung Surabaya. Surabaya: Jurnal Ekonomi Manajemen, Fakultas Ekonomi Universitas Kristen Petra Vol 10 no 1.

Valerie Zeithaml, Mary Jo Bitner, Dwayne D. Gremler . 2006. Services Marketing. Mc Graw Hill. New York.

Wibowo. 2013. Perilaku dalam organisasi. Jakarta: Raja grafindo persada 